\title{
Parental Involvement, Interest In Schooling And Science Achievement Of Junior Secondary School Students In Ogun State, Nigeria
}

R.A. Olatoye, Olabisi Onabanjo University, Nigeria B.J. Ogunkola, Olabisi Onabanjo University, Nigeria

\begin{abstract}
This study investigated the relative and combined influences of parental involvement and interest in schooling on science achievement of selected Junior Secondary School students in Ogun State, Nigeria. Twelve secondary schools were selected from the four administrative divisions of the State. A sample of 360 students participated in the study and three instruments were used to collect data. The combined influence of parental involvement and interest in schooling accounted for $7.3 \%$ of the total variance in science achievement ( $R$ Square $=0.073, p<0.05$ ), which is a significant percentage. There was a significant relationship between parental involvement and science achievement $(r=+0.167, p<0.05)$ as well as between interest in schooling and science achievement $(r=+0.253, p<0.05)$. Parents, teachers, and counselors should provide a stimulating learning environment in order to sustain students' interest in school.
\end{abstract}

Keywords: Parental involvement, interest in schooling, science achievement, Upper Basic Education, Ogun State.

\section{INTRODUCTION}

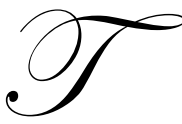

raditionally, parental involvement in education included contribution to their children's home-based activities (helping with home-work, encouraging children to read, and promoting school attendance) and school-based activities (attending Parent-Teachers' Association meetings, parent-teacher conferences, and participating in fun raising activities). Hixson (2006) explained that involvement of parents and families is often cited as one of the most important ways to improve public schools. Parental involvement makes an enormous impact on the student's attitude, attendance, and academic achievement and it promotes better cooperation between parents and school. It also allows parents and teachers to combine efforts to help the children succeed in school.

Epstein (1995) identified six areas of parental involvement in their children's academic activities: parenting, communicating, volunteering, learning at home, decision-making, and collaborating with the community. If parents are actively involved in these areas, no doubt it will stimulate children's interest in school and positively influence academic achievement. Keith, Quirk, Sperduto, Santillo, and Killings (1998) found that parental involvement influences the student's grade average and that the same influence holds across gender, but not across ethic groups. Paulson (1994) examined some college students regarding their parents' responsiveness, school involvement interest, and commitment to achievement. Boys reported that both maternal and paternal support significantly predicted their achievement; however, girls reported that parental involvement and style did not predict their achievement. Based on findings from this study, therefore, parental involvement seems to be sensitive to student gender. 
Parental involvement cannot work alone to influence school outcomes. The cooperation of students with their parents and teachers can be very valuable. A student should be willing to learn, take interest, and participate fully in academic activities before he or she can benefit from school. Sarason (1983) observed that schools are no longer interesting places for most of the students; however, this type of observation may vary from place to place or even from school to school in a particular area. Yet attention should be given to how interest influences school achievement. Maduabam (2001) also noted that many students now take more interest in a certificate than in what they can gain in school because of the scourge of examination malpractices and over-emphasis on paper qualification. Contrary to these findings, Olatoye (2004a) found that the level of student interest in school and study habits was above average and a significant positive relationship. There was no significant difference between male and female interest in school.

In Nigeria, student performance in science, both at the internal and external examinations, has been consistently poor (Olatoye, 2004b, Salami, 2000, Ogunniyi, 1996). Areola (1998) evaluated the implementation of the Nigeria Integrated Science programme and found that student performance in science was generally poor in all nine of the Nigerian states selected for the study. The average performance was not up to $50 \%$ in any school, while it was below $40 \%$ in most schools.

All the great nations of the world, like the United States, Britain, Germany, and Japan, have also developed in science and technology. Therefore, research attention should be geared toward factors that influence science achievement. Fortunately, science by nature is a human activity that is concerned with the exploration and interpretation of the natural world, so science can be learned both inside and outside the school. The role of parents in providing necessary materials, supporting extra lessons in school, motivating students to study science, and citing environmental problems that science has been able to solve can go a long way in influencing student achievement in science and interest in school. Students should also cooperate with their teachers in order for their efforts to have a positive impact on science achievement. This study, therefore, investigated relative and combined influences of parental involvement and interest in school on students' science achievement in the Upper Basic Education (otherwise known as Junior Secondary School) in Ogun State.

\section{Research Questions}

1. To what extent will students' parental involvement and interest in school predict science achievement?

2. What is the relative influence of parental involvement alone on science achievement?

3. What is the relative influence of interest in school on science achievement?

4. What are the relationships among students' parental involvement, interest in school, and science achievement?

5. Is there any significant difference between male and female students' parental involvement, interest in school, and science achievement?

\section{METHOD}

\section{Research Design}

This study adopted an expost-facto research design where the independent variables have already occurred and the researcher cannot manipulate them.

\section{Target Population And Sample}

The target population for this study was all Junior Secondary School students in Ogun State. In order to ensure that each school had an equal chance of being chosen, a random sampling technique was used to select three junior secondary schools from each of the four divisions (for a total of 12). Thirty students were then randomly selected from each school, so a total of 360 students participated in this study. 


\title{
Instrumentation
}

\author{
Three questionnaires were designed and used to collect data: \\ 1. $\quad$ Students' Parental Involvement Questionnaire (SPIQ) \\ 2. $\quad$ Students' Interest in School Questionnaire (SISQ) \\ 3. Students' Science Achievement Test (SSAT)
}

The initial versions were given to experts for their input before completing the final questionnaires. SPIQ and SISQ are four-point Likert-type scales. Students were asked to indicate their opinion s by ticking 'Strongly Agree', 'Agree', 'Disagree', or 'Strongly Disagree' for each statement. The SPIQ and SISQ consist of 10 and 13 items respectively. To keep anonymous, the students were not asked to indicate their names on the questionnaires. The Cronbach alpha reliability co-efficients of $0.781,0.701$, and 0.776 were obtained for SPIQ, SISQ, and SSAT respectively.

SSAT is a 50-item multiple-choice objective test with four options for each item. The items cover many of the topics in the Junior Secondary School integrated science syllabus.

\section{Examples of items on SPIQ}

1. My parents/guardians always check my take-home assignments.

2. My parents/guardians come to my school regularly to find out my academic progress.

\section{Examples of items on SSIQ:}

1. Life in school is exciting to me.

2. I have always enjoyed studying in school.

\section{Examples of items on SSAT:}

1. The transfer of traits from parents to offspring is known as: A. Fertilization, B. Progeny, C. Heredity, D. Conception.

2. Air pressure is measured with a: A. Thermometer, B. Rain guage, C. Barometer, D. Sonometer.

3. Echo is an example of D. Dispersion. of sound: A. Refraction, B. Reflection, C. Diffraction,

\section{Data Analysis}

Data were analyzed using regression analysis for research questions 1 to 3 , Pearson product-moment correlation for research question 4 , and t-test for research question 5. The research questions were answered using a two-tailed test at 0.05 level of confidence.

\section{RESULTS}

\section{Research Question 1}

To what extent will student parental involvement and motivation for examinations predict science achievement?

Table 1 shows that parental involvement and interest in school, when taken together, accounted for $7.3 \%$ of the total variance in student science achievement $(\mathrm{R}$ Square $=0.073, \mathrm{p}<0.05)$. This percentage, though low, is statistically significant. The low percentage only shows that there are other factors (besides involvement and interest in school that were considered for this study) that can also explain science achievement. Thus, these two independent variables are important predictors of science achievement. 
Table 1: Combined influence of parental involvement and interest in school on science achievement

\begin{tabular}{|c|c|c|c|c|c|c|}
\hline \multicolumn{7}{|c|}{$\begin{array}{c}\mathrm{R}=0.270 \\
\mathrm{R} \text { Square }=0.073 \\
\text { Adjusted R Square }=0.068 \\
\text { Standard Error }=6.635\end{array}$} \\
\hline \multicolumn{7}{|c|}{ Analysis of variance } \\
\hline & $\begin{array}{l}\text { Sum of } \\
\text { Squares }\end{array}$ & Df & $\begin{array}{l}\text { Mean } \\
\text { Square }\end{array}$ & $\mathbf{F}$ & $\mathbf{p}$ & Remark \\
\hline Regression & 1232.430 & 2 & 616.215 & 13.996 & 0.000 & $*$ \\
\hline Residual & 15718.359 & 357 & 44.029 & & & \\
\hline Total & 16950.789 & 359 & & & & \\
\hline
\end{tabular}

* Significant $(\mathrm{p}<0.05)$

\section{Research Question 2}

What is the relative influence of parental involvement alone on science achievement?

Table 2: Parental involvement as a predictor of science achievement

\begin{tabular}{|c|c|c|c|c|c|c|}
\hline \multicolumn{7}{|c|}{$\begin{array}{c}\mathrm{R}=0.202 \\
\mathrm{R} \text { Square }=0.041 \\
\text { Adjusted R Square }=0.038 \\
\text { Standard Error }=6.789\end{array}$} \\
\hline \multicolumn{7}{|c|}{ Analysis of variance } \\
\hline & $\begin{array}{l}\text { Sum of } \\
\text { squares }\end{array}$ & Df & $\begin{array}{l}\text { Mean } \\
\text { Square }\end{array}$ & $\mathbf{F}$ & $\mathbf{P}$ & Remark \\
\hline Regression & 693.331 & 1 & 63.331 & 15.268 & 0.000 & $*$ \\
\hline Residual & 16257.458 & 358 & 45.412 & & & \\
\hline Total & 16950.789 & 359 & & & & \\
\hline
\end{tabular}

* Significant $(\mathrm{p}<0.05)$

Table 2 shows that parental involvement singularly accounted for $4.1 \%$ of the total variance in science achievement $(\mathrm{R}$ Square $=0.041, \mathrm{p}<0.05)$. This percentage, though low, is shown to be statistically significant. Thus, parental involvement is an important factor in predicting science achievement.

\section{Research Question 3}

What is relative influence of interest in school alone on science achievement?

Table 3: Student interest in schooling as a predictor of science achievement

\begin{tabular}{|c|c|c|c|c|c|c|}
\hline \multicolumn{7}{|c|}{$\begin{array}{c}\text { R Square }=0.064 \\
\text { Adjusted R Square }=0.061 \\
\text { Standard Error }=6.648\end{array}$} \\
\hline \multicolumn{7}{|c|}{ Analysis of variance } \\
\hline & $\begin{array}{l}\text { Sum of } \\
\text { squares }\end{array}$ & Df & $\begin{array}{l}\text { Mean } \\
\text { Square }\end{array}$ & $\mathbf{F}$ & $\mathbf{p}$ & Remark \\
\hline Regression & 1081.526 & 1 & 1081.526 & 24.399 & 0.000 & $*$ \\
\hline Residual & 15869.263 & 358 & & & & \\
\hline Total & 16950.789 & 359 & & & & \\
\hline
\end{tabular}

* Significant $(\mathrm{p}<0.05)$ 
Table 3 shows that interest in school singularly accounted for $6.4 \%$ of the total variance in science achievement $(\mathrm{R}$ Square $=0.064, \mathrm{p}<0.05)$. This percentage, though low, is shown to be statistically significant. Thus, interest in school is an important factor in predicting science achievement.

\section{Research Question 4} achievement?

What are the relationships among students' parental involvement, interest in school, and science

Table 4: Correlation matrix of parental involvement, interest in school and science achievement

\begin{tabular}{lccc}
\hline & Parental involvement & Motivation & Science Achievement \\
Parental Involvement & 1.000 & & \\
Motivation & $0.856^{*}$ & 1.000 & 1.000 \\
Science Achievement & $0.167^{*}$ & $0.253^{*}$ & \\
\hline
\end{tabular}

* Significant $(\mathrm{p}<0.05)$

There are significant positive relationships between parental involvement and science achievement $(r=+0.167, p<0.05)$ and between interest in school and science achievement $(r=+0.253, p<0.05)$. However, the highest positive significant relationship is between parental involvement and interest in school $(\mathrm{r}=+0.856, \mathrm{p}<0.05)$.

\section{Research Question 5}

Is there any significant difference between male and female students':

1. Parental Involvement

2. Interest in school

3. Science achievement

Table 5: Comparison of male and female students' parental involvement, interest in school, and science achievement

\begin{tabular}{|c|c|c|c|c|c|c|c|c|c|}
\hline Variable & Gender & $\mathrm{N}$ & Mean & $\begin{array}{l}\text { Std. } \\
\text { Dev }\end{array}$ & $\begin{array}{l}\text { Std. } \\
\text { Error }\end{array}$ & df & $\mathrm{t}$ & $\mathrm{p}$ & Remark \\
\hline \multirow[t]{2}{*}{ Parental involvement } & Male & 181 & 27.696 & 6.474 & 0.481 & \multirow[t]{2}{*}{358} & \multirow[t]{2}{*}{0.988} & \multirow[t]{2}{*}{0.324} & \multirow[t]{2}{*}{ NS } \\
\hline & Female & 179 & 27.022 & 6.470 & 0.484 & & & & \\
\hline \multirow{2}{*}{$\begin{array}{l}\text { Motivation } \\
\text { examination }\end{array}$} & Male & 181 & 23.906 & 5.356 & 0.398 & 358 & -0.464 & 0.643 & NS \\
\hline & Female & 179 & 24.168 & 5.337 & 0.399 & & & & \\
\hline \multirow[t]{2}{*}{ Science achievement } & Male & 181 & 19.149 & 6.638 & 0.493 & 358 & -0.711 & 0.477 & NS \\
\hline & Female & 179 & 19.665 & 7.109 & 0.531 & & & & \\
\hline
\end{tabular}

NS = Not significant $(p>0.05)$

There is no significant different between male and female students' parental involvement, motivation for examinations, and student science achievement. It should be noted that students' average achievement in science is still below average. The mean achievements of male and female students are 19.149 and 19.665 respectively. The mean is below average because the maximum obtainable score in the science test administered is 50 .

\section{DISCUSSION}

Parental involvement and interest in school were combined to significantly predict students' academic achievement in science. These two independent variables also have significant relative influence on science achievement, which implies that students' parental involvement and interest in school are important predictors of science achievement. Parents are in the position to help, counsel, and support their children socially, academically, and emotionally to achieve better grades in science. This view corroborates the findings from many studies (Hixon, 
2006; Epstein, 1995) which reported that parental involvement could help improve students' achievement in school. Baker and Soden (1998) enumerated areas where parents could be involved in their children's academic activities: provision of stimulating literacy materials at home, supervision of homework, monitoring of television viewing, and participation in joint learning activities at home.

Interest in school is also a significant predictor of science achievement. Fagbemi (2001) and Olatoye (2004a) reported that low performance in school is a direct influence of students' unwillingness to learn. Many students are only interested in certification, which is the reason why many students engage in examination malpractices. Sarason (1983) also reported that many students are no longer interested in school. Once there is no interest in learning or schooling, the amount of time scheduled for study will also be reduced. No doubt, parents have roles to play in ensuring that interest in school is aroused and sustained. The highest significant relationship among the three variables considered in this study is between parental involvement and interest in school (Table 4). This relationship is greater than that between parental involvement and science achievement and between interest in school and science achievement.

There is no significant difference in level of parental involvement in male and female children's academic activities. This is contrary to the study of Paulson (1994) who reported that parental involvement predicted achievement for boys, but not for girls. However, this study corroborates that of Keith el at (1998) who reported that there is no significant difference in parental involvement influence on students' achievement across gender. In this study, there is also no significant difference between male and female students' achievement in science. Gorman (2006) and Olatoye (2002) reported a significant difference in favour of male students.

\section{CONCLUSION AND RECOMMENDATIONS}

Parents are in the position to put their children on the right course, especially at the early stage of development. The parental roles continue to impact on children's lifestyle, perhaps throughout life. Interest in schooling, when stimulated and sustained, can enhance student achievement in science. The contribution of the two independent variables is significant on science achievement. The low percentage contribution of the two independent variables to science achievement only shows there are other factors that account for the remaining variance in science achievement. Such factors may be self-concept, test anxiety, availability, and use of instructional materials, to mention few. Parents should make sure they complement teachers' efforts in school by monitoring and supervising their children's academic activities in order to enhance science achievement. Teachers, parents, and school counselors alike should make school an interesting place to learn in order to sustain student's interest in schooling. Necessary materials should be provided to remove frustration in the process of learning.

\section{AUTHOR INFORMATION}

Dr. Olatoye R.A is a Research Fellow at Institute of Education, Olabisi Onabanjo University Ago-Iwoye, Nigeria. $\mathrm{He}$ holds a PhD degree in Educational Evaluation. His areas of interest are Science Education, Educational Evaluation, and Educational Statistics. He is also an expert in quantitative measurement and data processing. He has published many scholarly papers in reputable journals and has attended many conferences within and outside his country of Nigeria. He has also been involved in editing of books and journals. He is an Executive Editorial Board member of Intellectbase International Consortium based in Nashville, Tennessee, USA.

Dr. Babalola J. Ogunkola is a Senior Research Fellow and the current Sub-Dean of the Faculty of Education, Olabisi Onabanjo University Ago-Iwoye, Nigeria. He holds a PhD Degree in Educational Evaluation. He has published in several local and international journals, most in the areas of Evaluation of science students' achievement and teaching effectiveness in science education. He is also an author of books and has attended many conferences within and outside his country of Nigeria. He is an Executive Editorial Board member of Intellectbase International Consortium based in Nashville, Tennessee, USA. 


\section{REFERENCES}

1. Areola, O.O. (1998). An evaluation of the implementation of Nigerian Integrated Science Programme in some Selected States. An Unpublished PhD Thesis University of Ibadan, Ibadan.

2. Baker, A.J.L. \& Soden, L.M. (1998). The challenges of parent involvement research. ERIC/CUE Digest Number 134, New York: ERIC Clearinghouse on Urban Education, Institute for Urban and Minority Education.

3. Epstein, J.L. (1995). School/Family/Community partnerships: Caring for the children we share. Phi Delta Kappan, 76(9), 701-712.

4. Gorman, L. (2006). Teacher and the gender gaps in student achievement. US: National Bureau of Economic Research.

5. Hixon, J. (2006). Critical Issues Supporting Ways Parents and Families can becomes involved in Schools. Cambridge: Harvard Family Research Project.

6. $\quad$ Keith, T.Z., Kenith, P.B., Quirk, K.J., Sperduth, J., Santillo, S. \& Killings, S (1998). Longitudinal effects of parents involvement on high school grades: Similarities and differences across gender and ethnic groups. Journal of School Psychology, 36(3), 335-63

7. Ogunniyi, M.B. (1996). Science, Technology and Mathematics: The Problem of developing critical capital in Africa. International Journal of Science Education, 18(3), 267-284.

8. Olatoye, R.A. (2002). A causal model of school factors as determinants of science achievement in Lagos State Secondary Schools. An Unpublished PhD Thesis, University of Ibadan, Nigeria.

9. Olatoye, R.A. (2004a). Interest in schooling as a determinant of Secondary School Students' Study Habit. International Journal of Literacy Education. Published by Adult Education Department, University of Ibadan.

10. Olatoye, R.A. (2004b). Emergent Issues in Enhancing the Teaching and Learning of Science in Schools. In O.A. Afemikhe, J.B. Adewale (Eds). Issues in Educational Measurement and Evaluation in Nigeria. Pp. 102-114. Published by Institute of Education, Educational University of Ibadan, Ibadan.

11. Paulson, S.E. (1994). Parenting style and parental involvement: Relations with adolescent achievement. Midwestern Educational Researcher, 7(1), 6-11.

12. Salim, B. (2000). JAMB results released. The Daily Times, July 27, p 1.

13. Sarason, S. (1983). Schooling in America. New York: Free Press. 
NOTES 